\title{
Diet composition of the Long-eared Owl (Asio otus) in the Eastern Anatolia (Turkey)
}

\author{
Ahmet Yesari Selçuk ${ }^{a, *}$ (i), Ömral Ünsal Özkoça ${ }^{a}$, Mehmet Akif Bilira ${ }^{a}$ ib , Haluk Kefelioğlua
}

\begin{abstract}
In this study, pellet compositions of Long-eared Owl (Asio otus) were analysed. The primary aim of this study was to investigate the diet composition of Long-eared Owl in high altitude steppe in summer. Compositions of 130 pellets of Longeared Owl were used in the study. 147 preys (1.13 preys per pellet) which belong to 9 different taxa were found in pellet composition. A significant part of the diet in study area consisted of small mammals. Only two remains of birds were recorded from pellets. Microtus sp. was found important prey in the diet of Long-eared Owl (F=81.63\%, B = 78.21\%). Since Microtus $\mathrm{sp}$. is the favourite prey of Long-eared Owl, this situation causes a negative correlation with the prey variety in diet composition. For this reason, FNB and Shannon-Wiener indices had low levels, Shannon-Wiener $\left(H^{\prime}\right)$ value was found to be low for Longeared Owl.
\end{abstract}

Keywords: Dietary diversity, Kars, Microtus, Pellets, Summer diet

\section{Kulaklı Orman Baykuşu'nun (Asio otus) Doğu Anadolu Bölgesindeki diyet kompozisyonu}

\begin{abstract}
Özet: Bu çalışmada kulaklı orman baykuşunun (Asio otus) pelet içerikleri analiz edilmiştir. Bu çalışmanın temel amacı, kulaklı orman baykuşunun yaz mevsiminde bir dağ bozkırındaki diyet kompozisyonunu araştırmaktır. Kulaklı orman baykuşuna ait 130 pelet içeriği çalışmada kullanılmıştır. Pelet içeriğinden 9 farklı taksona ait 147 av (pelet başına 1.13 av) olduğu belirlendi. Küçük memeliler türün diyetinin en önemli kısmını oluşturmaktadır. Yalnızca iki tane kuş kalıntısına peletlerde rastlanmıştır. Microtus sp., türün diyetinde önemli bir av olarak tespit edildi $(\mathrm{F}=\%$ 81.63, $\mathrm{B}=\%$ 78.21). Microtus sp. kulaklı orman baykuşunun favori avı olduğu için bu durum diyet içeriğindeki av çeşitliliği ile negatif korelasyona sebep olmaktadır. Bu nedenle FNB ve ShannonWiener indeksi düşük değerdedir.

Anahtar Kelimeler: Diyet çeşitliliği, Kars, Microtus, Pelet, Yaz mevsimi diyeti
\end{abstract}

\section{Introduction}

Diet content studies are helpful in determining the distribution of preys, prey abundance and hunting strategies of birds (Torre et al., 2004). Many different methods such as pellet analysis, stomach content analysis, regurgitation of juvenile birds, fecal content examination of prey remains in the nest and around the feeding area and direct examination are used in finding out prey preferences (Duffy and Jackson, 1986; Marti, 1987). Pellet analysis is a frequently used method in finding out feeding strategies of owls (Terry, 2008). The pellets contain mammal bones such as the skulls and mandibles. Those remains are useful to identification of small mammals at the genus and even species level. Therefore, many significant information can be provided about the composition of small mammal within preying areas of owls and their diet preferences (Yalden, 2009). Long-eared Owl (Asio otus) is an opportunist species which is distributed widely in Holarctic region (Mebs and Scherzinger, 2000). While Vole (Microtus spp.) and Mice (Apodemus spp., Mus spp.) species form the main nutritional source of Long-eared Owl, diet composition can differ depending on geographical and climatic factors (Romanowski and Zmihorski, 2008).

Long-eared Owl is a resident and wintering bird species and also one of the most common owl species throughout most of the country, but rather more local in Eastern Anatolia. It is found in different types of habitat with trees such as forest, wooded areas, plantations areas, parks and gardens in urban areas (Kirwan et al., 2008). The primary aim of this study was to investigate the diet composition of Long-eared Owl in high altitude steppe.

\section{Material and methods}

\subsection{Research area}

This study was conducted in the province of Kars in Eastern Anatolia region in 2018 (N40 $\left.27^{\prime}-\mathrm{E} 42^{\circ} 49^{\prime}\right)$. The pellets were collected in $29^{\text {th }}$ of July 2018. Pellets of Longeared Owl were obtained from Scots pine (Pinus sylvestris) plantation areas which surrounded by agricultural fields. This plantation area is located within the high steppe at 2200 meter altitude in the province of Kars. The distance of

\footnotetext{
$\triangle$ a Department of Biology, Faculty of Science, Ondokuz Mayis University, 55200, Samsun - Turkey

@ * Corresponding author (İletişim yazarı): ahmetyesari@gmail.com

$\checkmark \quad$ Received (Geliş tarihi): 21.01.2019, Accepted (Kabul tarihi): 27.03.2019
}

Citation (Atıf): Selçuk, A.Y., Özkoç, Ö.Ü., Bilir, M.A., Kefelioğlu, H., 2019. Diet composition of the Long-eared Owl (Asio otus) in the Eastern Anatolia (Turkey). Turkish Journal of Forestry, 20(2): 72-75. DOI: $\underline{10.18182 / \mathrm{tjf} .515832}$ 
Scots pines to each other is approximate 3 meters. Pellets were scattered in the area and were not collected under a particular tree. The study area is a breeding site of Longeared Owl. The highest observed number is 13 individuals at once in the study area and all of them were juvenile Long-eared Owls. The average temperature in July is $17.6{ }^{\circ} \mathrm{C}$ and the average rainfall was $57.6 \mathrm{~mm}$. The average annual temperature was $4.9^{\circ} \mathrm{C}$ and the average rainfall is 499.8 mm (MGM, 2018).

\subsection{Research method and data analysis}

Small mammal identification was made according to Kryštufek and Vohralik (2005, 2009). Biomass was calculated as the sum of the masses of all individuals of the prey species. The geographic, sex and individual-related differences in terms of biomass can vary among the many species. Other papers containing data on mean values of sex and age groups of prey would be very helpful for the calculations of biomass (Birrer, 2009). For this reason, while calculation of mammal biomass, the data in Kryštufek and Vohralik (2005, 2009)'s studies, which reflects Turkey sample, were taken into consideration. Skull and mandibula were used for the identification of small mammals. The minimum number of individuals (MNI) of small mammal and bird taxa inside the pellet composition, frequency $(\mathrm{F} \%)$, biomass (B\%), average prey amount for each pellet and biomass rates were calculated. For statistical analysis, Food Niche Breadth (FNB) index was calculated according to Levin's (1968) formula: $1 / \Sigma \mathrm{pi}^{2}$, where pi denotes contribution of a given prey group to the diet. ShannonWiener Index $\left(H^{\prime}\right.$; Formula $=-\sum$ piln $(\mathrm{pi})$; 'pi' is the proportion of species in the entire sample, ' $l n$ ' is the natural logarithm) (Krebs, 1994) which shows the species richness in the diet and the individual numbers between taxa and Evenness Index $\left(\mathrm{J}\right.$; formula $=H^{\prime} / \operatorname{logS} ; \mathrm{S}$ number of the species in the pellets, $\mathrm{J}^{\prime} ; 0=$ individuals not equally distributed, 1 = individuals equally distributed) which shows the distribution of individuals (regular/irregular) within the diet were used.

\section{Results}

As a result of the analysis of 130 pellets of Long-eared Owl, 147 preys of nine different small mammal taxa and two bird preys (unidentified) were found in pellet composition (Table 1). Small mammals constitute a significant part of the diet composition ( $\mathrm{F}=98.64 \%$, $\mathrm{B}=99.28 \%)$. Microtus spp. $(\mathrm{F}=81.63 \%, \mathrm{~B}=78.21)$ is the dominant prey in the diet preference of Long-eared Owl. The remains which belong to Microtus sp. were found in $78 \%$ of the pellets. Following Microtus sp., Apodemus sp. $(\mathrm{F}=6.80 \%, \mathrm{~B}=4.84 \%)$ was the highest rated taxon within diet composition (Table 1). Although Mesocricetus brandti had a low frequency in diet composition, it was found to be the highest biomass rate, following Microtus sp. It was determined that very low frequency of bird remains in the pellet composition of the Long-eared Owl. While the rate of prey per pellet was 1.13 , the rate of biomass was $42.96 \mathrm{~g}$ (Table 1).
Table 1. Diet composition of Long-eared Owl from Eastern Turkey, minimum number of individuals Frequency (F\%), Biomass (B\%), statistical analyses.

\begin{tabular}{|c|c|c|c|c|}
\hline Species & $\begin{array}{l}\text { Mean body } \\
\text { weight }(\mathrm{g})\end{array}$ & $\mathrm{MNI}$ & $\mathrm{F} \%$ & $\mathrm{~B} \%$ \\
\hline$\overline{\text { Arvicola amphibius }}$ & 170.0 & 1 & 0.68 & 3.04 \\
\hline Microtus sp. & 36.4 & 120 & 81.63 & 78.21 \\
\hline Cricetulus migratorius & 32.1 & 3 & 2.04 & 1.72 \\
\hline Mesocricetus brandti & 108.7 & 5 & 3.40 & 9.73 \\
\hline Apodemus witherbyi & 24.0 & 3 & 2.04 & 1.29 \\
\hline Apodemus uralensis & 20.2 & 5 & 3.40 & 1.81 \\
\hline Apodemus mystacinus & 48.7 & 2 & 1.36 & 1.74 \\
\hline Mus sp. & 16.1 & 6 & 4.08 & 1.73 \\
\hline Mammals total & & 145 & 98.64 & 99.28 \\
\hline Birds & 20.0 & 2 & 1.36 & 0.72 \\
\hline Birds total & & 2 & 1.36 & 0.72 \\
\hline Total pellet & \multicolumn{4}{|c|}{130} \\
\hline Total prey item & \multicolumn{4}{|c|}{147} \\
\hline Mean number prey/pellet & \multicolumn{4}{|c|}{1.13 [min-max: 1-2] } \\
\hline Mean prey biomass/pellet (g) & \multicolumn{4}{|c|}{42.96} \\
\hline FNB & \multicolumn{4}{|c|}{1.49} \\
\hline Shannon-Wiener index $\left(H^{\prime}\right)$ & \multicolumn{4}{|c|}{0.82} \\
\hline Evenness index (J') & \multicolumn{4}{|c|}{0.37} \\
\hline
\end{tabular}

\section{Discussion and conclusions}

In previous studies which have been conducted to find out the diet of Long-eared Owl, most of the diet composition consists of Vole species as dominant preys (Birrer, 2009). Although Vole species (or Sigmodon spp. which are ecologically similar to Vole species, Williford, 2011) constitute the main prey of Long-eared Owl, other prey groups can also have high rates in diet composition (for birds, Kiat et al., 2008; Sándor and Kiss, 2008; for bats, Tian et al., 2015). A total of 475 studies on the dietary content of the Long-eared Owl were collected by Birrer (2009). With the data set obtained in this study, 477 species were identified as prey of the Long-eared Owl. Among these species, $180(37.74 \%)$ were small mammals and 191 $(40.04 \%)$ were birds. Although the rate of the bird taxa is higher in terms of prey variety, $93.3 \%$ of vertebrate prey are small mammal species, $6.4 \%$ are birds and $0.3 \%$ are other vertebrates. Although the number of bird species is higher than small mammal species, the main preys of Long-eared Owl consist of small mammals. Similarly, small mammal species were dominant preys in this study $(98.64 \%)$. Göçer (2016) found bird remains at a rate of $100 \%$ in an urban area in Southwestern Turkey. Similar of this exceptional situation had been found in a few other studies (Sándor and Kiss, 2008; Kiat et al., 2008). However, pellets in these studies were collected from natural habitats unlike in Turkey. According to the optimal nutritional theory summarized by Pyke (1984), the diversity and rates in the diet depend on the abundance and availability of the most important prey. At the same time, it is stated that the Longeared Owl prey on more birds when small mammals are low density and it is difficult to access to those preys (Milchev and Ivanov, 2016). The reason of that only birds were found from pellets collected in the urban area in Turkey could be that rodent populations are negatively affected by anthropogenic effects. This situation indicates that the Long-eared Owl is an opportunistic predator, as referred in various publications (Bertolino et al., 2001; Tulis et al., 2015).

The most important factors determining the distribution rates of prey in the diet of the Long-eared Owl are probably the size of the prey and its abundance in the area (Birrer, 
2009; Pyke, 1984). It is reported that animals lighter than $300 \mathrm{~g}$ are potential prey, but animals lighter than $50 \mathrm{~g}$ are more dominant, as is the case with Microtus species (Birrer, 2009).

On the other hand, in different habitats, the main prey can consist of Rats Rattus spp. (Pirovano et al., 2000), Wood Mouse Apodemus spp. (Bertolino et al., 2001), and Mice Mus spp. (Song et al., 2010) groups rather than Voles Microtus spp. in diet composition. The reason for this situation could be that Long-eared Owl prefers the more abundant preys in the area because the small mammal composition is related to habitat types.

In studies conducted in different localities and different habitats of Turkey, Voles (Microtus spp.) are the main prey in the diet of Long-eared Owl (Asio otus). The only exception of this situation is the study conducted to find out the diet composition in breeding period in city center populations reported by Göçer (2016) (Table 2). Since
Microtus spp. is the favorite prey of Long-eared Owl, this situation causes a negative correlation with the prey variety in diet composition (Mori and Bertolino, 2015). For this reason, FNB and Shannon-Wiener indices have low levels. As recorded in other studies, the diet content of the Longeared Owl depends on different factors which related to each other such as season, geographical location, breeding or non-breeding area, abundance and attractiveness of prey, behaviour of the prey and the climatic conditions (Birrer, 2009).

As a conclusion, a significant part of the diet of Long-eared Owls in study area consisted of small mammals. Bird remains were recorded as only two individuals. In order to better understand the diet of Long-eared Owl and to determine which variables affect the diet, more studies are needed with pellets collected from different habitat types, localities and seasons.

Table 2. Diet composition of Long-eared Owl in different habitats, seasons and localities of Turkey, Central Anatolia (CA), Southeastern Anatolia (SEA), Southwestern Anatolia (SWA), Northern Anatolia (NA), Eastern Anatolia (EA), Frequency (F\%).

\begin{tabular}{|c|c|c|c|c|c|c|c|c|c|c|}
\hline & & & $\begin{array}{l}\text { Turan, } \\
2005 \\
\text { (CA), } \\
\text { Winter }\end{array}$ & $\begin{array}{c}\text { Seçkin and } \\
\text { Çoşkun } \\
(2006) \\
\text { (SEA), } \\
\text { One-year }\end{array}$ & $\begin{array}{l}\text { Bulut et al. } \\
\text { (2012) } \\
\text { (CA), } \\
\text { Spring and } \\
\text { Summer }\end{array}$ & $\begin{array}{c}\text { Hizal (2013) } \\
\text { (CA), } \\
\text { One-year }\end{array}$ & $\begin{array}{c}\text { Göçer } \\
\text { (2016) } \\
\text { (SWA), } \\
\text { Spring } \\
\text { and } \\
\text { Summer }\end{array}$ & $\begin{array}{c}\text { Selçuk et al. } \\
\text { (2017) } \\
\text { (NA), } \\
\text { Winter }\end{array}$ & $\begin{array}{c}\text { Kaya and } \\
\text { Çoşkun } \\
(2017) \\
\text { (EA), } \\
\text { One-year }\end{array}$ & $\begin{array}{c}\text { In this study } \\
\text { (EA), } \\
\text { Summer }\end{array}$ \\
\hline & \multirow[t]{2}{*}{ Family } & \multirow[t]{2}{*}{ Species } & $\begin{array}{c}\text { Naturel } \\
\text { area }\end{array}$ & $\begin{array}{c}\text { Agricultural } \\
\text { area }\end{array}$ & $\begin{array}{c}\text { Suburban } \\
\text { area }\end{array}$ & $\begin{array}{c}\text { Meadow and } \\
\text { agricultural } \\
\text { area }\end{array}$ & $\begin{array}{c}\text { City } \\
\text { center }\end{array}$ & $\begin{array}{c}\text { Steppe and } \\
\text { agricultural } \\
\text { area } \\
\end{array}$ & $\begin{array}{l}\text { Naturel } \\
\text { area }\end{array}$ & $\begin{array}{c}\text { Steppe and } \\
\text { agricultural } \\
\text { area }\end{array}$ \\
\hline & & & F\% & F\% & F\% & $\mathrm{F} \%$ & F\% & $\mathrm{F} \%$ & $\mathrm{~F} \%$ & $\mathrm{~F} \%$ \\
\hline Insectivora & Soricidae & Crocidura sp. & 3.7 & 4.5 & 2.8 & $<0.1$ & - & - & - & - \\
\hline \multirow{10}{*}{ Rodentia } & \multirow{4}{*}{ Cricetidae } & Arvicola sp. & - & - & - & - & - & - & - & 0.68 \\
\hline & & Microtus sp. & 44.4 & 73.2 & 68.6 & 84.6 & - & 64.9 & 87.4 & 81.63 \\
\hline & & Cricetulus sp. & - & 0.7 & 0.9 & 2.4 & - & 1.5 & 1.6 & 2.04 \\
\hline & & Mesocricetus sp. & - & - & - & 0.7 & - & 1.3 & 3.9 & 3.40 \\
\hline & \multirow{4}{*}{ Muridae } & Mus sp. & - & 19.4 & 10.8 & 3.9 & - & 28.4 & - & 4.08 \\
\hline & & Apodemus sp. & 25.0 & - & 11.3 & - & - & 0.9 & 0.7 & 6.80 \\
\hline & & Rattus sp. & - & 0.3 & 4.2 & - & - & - & - & - \\
\hline & & Meriones sp. & - & 1.6 & - & 1.6 & - & 2.8 & - & - \\
\hline & Dipodidae & Allactaga sp. & - & - & - & 0.6 & - & - & - & - \\
\hline & Spalacidae & Nannospalax sp. & - & 0.3 & 1.4 & - & - & - & - & - \\
\hline $\begin{array}{c}\text { Mammals } \\
\text { total }\end{array}$ & & & 73.1 & 100 & 100 & 93.9 & 0 & 100 & 93.6 & 98.64 \\
\hline $\begin{array}{l}\text { Aves } \\
\text { total }\end{array}$ & & & 26.9 & - & - & 4.1 & 100 & - & 5.9 & 1.36 \\
\hline $\begin{array}{c}\text { Insect } \\
\text { total }\end{array}$ & & & - & - & - & 2.0 & - & - & 0.5 & - \\
\hline
\end{tabular}




\section{Acknowledgement}

The pellets used in this study were obtained from the field study conducted as part of 'National Biological Variety Inventory and Monitoring Project (UBENIS)' conducted by the Ministry of Agriculture and Forestry Management. We would like to thank the Ministry of Agriculture Kars branch office employees for their contributions in the field surveys.

\section{References}

Bertolino, S., Ghiberti E., Perrone, A., 2001. Feeding ecology of the long-eared owl (Asio otus) in northern Italy: is it a dietary specialist?. Canadian Journal of Zoology, 79, 2192-2198.

Birrer, S., 2009. Synthesis of 312 studies on the diet of the longeared owl Asio otus. Ardea, 97, 615-24.

Bulut, Ş., Akbaba, B., Ayaş, Z., 2012. Analysis of mammal remains from owl pellets (Asio otus) in a suburban area in Beytepe, Ankara. Hacettepe Journal of Biology and Chemistry, 40, 233-237.

Duffy, D.C., Jackson, S., 1986. Diet studies of seabirds: a review of methods. Colonial Waterbirds, 9, 1-17.

Göçer, E., 2016. Diet of a nesting pair of Long-eared Owls, Asio otus, in an urban environment in southwestern Turkey (Aves: Strigidae). Zoology in the Midde East, 62, 25-28.

Hizal, E., 2013. Diet of the Long-eared Owl Asio otus, in Central Anatolia (Aves: Strigidae). Zoology in the Middle East, 59, $118-122$.

Kaya, A., Çoşkun, Y., 2017. Erzurum'dan Toplanan Kulaklı Orman Baykuşu (Asio otus) Peletlerinde Memeli Hayvan Türleri. BEU Journal of Sciene, 6, 47-50.

Kiat, Y., Perlman, G., Balaban, A., Leshem, Y., Izhaki, I., Charter, M., 2008. Feeding specialization of urban Long-eared Owls, Asio otus (Linnaeus, 1758), in Jerusalem, Israel. Zoology in the Middle East, 43, 49-54.

Kirwan, G. M., Boyla, K., Castell, P., Demirci, B., Özen, M. Welch, H., Marlow, T., 2008. The Birds of Turkey. Christopher Helm, London.

Krebs, C. J., 1994. Ecology: The Experimental Analysis of Distribution and Abundance. Harper Collins, New York.

Kryštufek, B., Vohralik, V., 2005. Mammals of Turkey and Cyprus. Order Rodentia I (Introduction, Checklist, Rodentia): Knjiznica Annales Majora, Koper.

Kryštufek, B., Vohralik V., 2009. Mammals of Turkey and Cyprus. Order Rodentia II (Introduction, Checklist, Rodentia): Knjiznica Annales Majora, Koper.

Levin, R., 1968. Evolution in changing environments; some theoretical explorations. Princeton University Press, Princeton, New York.

Marti, C. D., 1987. Raptor Food Habits Studies. Raptor Management Techniques Manual, 10, 67-79.

Mebs, T., Scherzinger, W., 2000. Die Eulen Europas. Kosmos, Stuttgart.
MGM 2018. Turkish state meteorological service, (https://www.mgm.gov.tr/) (Accessed: 28.12.2018)

Milchev, B., Ivanov, T., 2016. Winter diet of Long-eared Owls, Asio otus (L.) in a suburban landscape of North- Eastern Bulgaria. Acta Zoologica Bulgarica, 68, 355-361.

Mori, E., Bertolino, S., 2015. Feeding ecology of Long-eared Owls in winter: an urban perspective. Bird Study, 62, 257-261.

Pirovano, A., Rubolini, D., Brambilla, S., Ferrari, N., 2000. Winter diet of urban roosting long-eared owls Asio otus in Northern Italy: the importance of the brown rat Rattus norvegicus. Bird Study, 47, 242- 244.

Pyke, G. H., 1984. Optimal foraging theory: a critical review. Annual Review of Ecology, Evolution, and Systematics, 15, 523-575.

Romanowski, J., Zmihorski, M., 2008. Effect of season, weather and habitat on diet variation of a feeding specialist: a case study of the long-eared owl, Asio otus in Central Poland. Folia Zoologica, 57, 411-419.

Sándor, A. D., Kiss, B. J., 2008. Birds in the diet of wintering Long-eared Owls (Asio otus) in the Danube Delta, Romania. Journal of Raptor Research, 42, 292-295.

Seçkin, S., Çoşkun, Y., 2006. Small mammals in the diet of the Long-Eared Owl, Asio otus, from Diyarbakır, Turkey. Turkish Journal of Zoology, 30, 271-278.

Selçuk, A.Y., Bankoğlu, K., Kefelioğlu, H., 2017. Comparison of Winter Diet of Long-eared Owls Asio otus (L., 1758) and Short-eared Owls Asio flammeus (Pontoppidan, 1763) (Aves: Strigidae) in Northern Turkey. Acta Zoologica Bulgarica, 69, 345-348.

Song, S., Zhao, W., Zhao, J., Shao, M., Liu, N., 2010. Seasonal variation in the diet of Long-eared Owl, Asio otus, in the desert of Northwest China. Animal Biology, 60, 115-122.

Terry, R. C., 2008. Modeling the effects of predation, prey cycling, and time averaging on relative abundance in raptor-generated small mammal eath assemblages. Palaios, 23, 402-410.

Tian, L., Zhou, X., Shi, Y., Guo, Y., Bao, W., 2015. Bats as the main prey of wintering long-eared owl (Asio otus) in Beijing: Integrating biodiversity protection and urban management. Integrative Zoology, 10, 216-226.

Torre, I., Arrizabalaga, A., Flaquer, C., 2004. Three methods for assessing richness and composition of small mammal communities. Journal of Mammalogy, 85, 524-530.

Tulis, F., Baláž, M., Obuch, J., Šotnár, K., 2015. Responses of the long-eared owl Asio otus diet and the numbers of wintering individuals to changing abundance of the common vole Microtus arvalis. Biologia, 70(5), 667-673.

Turan, L., 2005. Winter diet of a Long-Eared Owl population in Ankara, Beytepe. Hacettepe Journal of Biology and Chemistry, 34, 69-76.

Williford, D., 2011. The winter diet of Short-eared Owls in subtropical Texas: Do southern diets provide evidence of opportunism. Journal of Raptor Research, 45, 63-70.

Yalden, D. W., 2009. The Analysis of Owl Pellets. 4th. ed. Mammal Society. 